Алла Шешкен

МГУ имени М.В. Ломоносова

Россия

https://doi.org/10.18485/ai_san_o_gradu.2020.ch3

821.161.1(497.11).09-1

Оригинални научни рад

\title{
ГРЁЗЫ О ПОТЕРЯННОЙ РОДИНЕ И ПЕТЕРБУРГЕ В ПОЭЗИИ «РУССКОГО БЕЛГРАДА»
}

Тема памяти занимает главное место в поэзии русской эмиграции первой волны, в том числе у поэтов «Русского Белграда» (И. Голенищев-Кутузов, Е. Таубер, И. Лапко, Ю. Лисовский и др.). Она тесно переплетена с темой родины и тоски по ней, для которой характерны размытость очертаний, нечеткость линий, литературность. Важнейшим орентиром для молодых поэтов была лирика А. Блока и образ Петербурга, созданный в его дореволюционной поэзии.

Ключевые слова: поэзия русской эмиграции первой волны, «Русский Белград», тема родины, мотив памяти, образ Петербурга, А. Блок, И. Голенищев-Кутузов.

Тема родины и тоски по ней занимают центральное место в литературе русского зарубежья. Исследователи давно обратили внимание, что образ России в творчестве эмиграции первой волны тесно связан с мотивом памяти и существенно отличается от изображения России в дореволюционных произведениях тех же авторов. Суровая реальность жизни вторгласть в лирику «старших эмигрантских поэтов», даже тех, кто утонченно парил в волшебном мире воображения 
и философских абстракций. Изменились тональность, пафос и авторское видение образа России. Самые яркие перемены произошли в изображении Петербурга и «петербургском тексте». ${ }^{1}$ Совокупный образ столицы империи, сложившийся из произведений XIX - начала XX вв. (от А. Пушкина до А. Блока), в 1920-1930-е гг. стал совсем другим, можно сказать, неузнаваемым. В прежнем образе города выделялась двойственность: соединялись черты царственности, великолепия, красоты и роскоши с нищетой, убийственной сыростью, грязью, «мрачными влияниями на душу человека» и порочными страстями. Вместе они создавали облик города, реальный и фантастический одновременно.

В эмиграции, оказавшись вдали от родины, поэты «забыли» хмурое небо и петебургскую сырость, вообще все то, что отталкивало и угнетало их в облике столицы в прошлом. Они рисуют Петербург в других - радостных и светлых красках. Эстет Г. Иванов, например, вспоминает не только Летний сад, но и «голубую белизну петербургского мая», что в реальности было и остается в Петербурге редкостью. Эта картина по своему настроению близка видениям о родных местах других поэтов. Москвич Г. Адамовича бредит «морозным и спящим Кремлем», сон наяву видит И. Северянин («И будет вскоре весенний день, и мы поедем домой в Россию...»), русские пейзажи воображает К. Бальмонт («незабудки», «пряное цветенье», «безбрежное поле, бездонная тишь»).

Особенно разительны были перемены в образе России и Петербурга в дореволюционной и эмигрантской поэзии Саши Черного. Обр+аз Петербурга предстает в его лирике 1910-х гг. подчеркнуто некрасивым и неприятным: мрачным, грязным, холодным, жестоким, губительным для искреннего чувства, обрекающим человека на

1 Топоров В.Н. Петербургский текст русской литературы: Избранные труды. Спб. 2003. 
духовную смерть. Сатириконовец Саша Черный «доводит это негативное отношение к «мрачному», «больному» городу-символу до абсолютного неприятия». ${ }^{2}$ Однако в эмигратских грезах лирическому герою Саши Черного видится совсем другой Петербург («Игрушки», «Невский», «Весна на Крестовском», «На островах»). Город становится для него символом исчезнувшей гармонии и счастья. Показательно название стихотворения «Мираж» (1923), основная мысль которого - недостижимое счастье видеть покинутую родину. Дети на корабле из песка (символичная деталь) мечтают доплыть до «Петрограда», они видят: «Вдали над пустыней седой/ Сияющей шапкой Исаакий/ Миражем вставал над водой».

Миражи и мечты о «потерянном рае» широко представлены в эмигрантской лирике и других поэтов, в том числе начавших свой творческий путь в Югославии. В цикле «Русская Помпея» Саша Черный выразил суть образа России в эмигрантской поэзии: «О родине каждый из нас вспоминая,/ В тоскующем сердце унес /Кто Волгу, кто мирные склоны Валдая,/ Кто заросли ялтинских роз..» . Ему вторит из Белграда малоизвестный поэт Ю. Лисовский: «где-то Крещатик, и где-то Литейный, где-то Заволжье, гдето Нева», упоминая известные улицы российских городов (киевский Крещатик и питерский Литейный проспект).

Поэзия «русских белградцев» имеет ряд общих типологических черт с поэзией, создававшейся в эмиграции в целом. В ней тоже лейтмотивом является образ родины, неразрывно связанный с темой памяти и тоски и образами-символами, олицетворяющими Россию, ее природу и историю. В то же время лирика поэтов «Русского Белграда» имеет особенности, обусловленные рядом обстоятельств, в том числе специфической средой этой

2 Тиботкина Н.А. Мотивная структура лирики Саши Черного. Автореф. дис. Кандидата филологических наук. Тверь 2010. С. 9. 
русской колонии и личной судьбой поэтов.

«Русский Белград» как историко-культурный феномен охватывает два межвоенных десятилетия. Он сложился в начале 1920-х гг., когда в столицу Королевства Сербров, Хорватов и Словенцев (с 1929 - Королевство Югославия) приехало значительное количество русских беженцев. С началом оккупации Югославии (1941) это явление угасло. ${ }^{3}$ Культурная активность русских и их вклад в сербскую культуру стали изучаться в Сербии и России в начале 1990-х гг. Богатейший архив, собранный А. Арсеньевым, и его публикации о русских колониях в Югославии, монография «Русская литературная Сербия» О. Джурича, исследования М. Стойнич, М. Сибиновича, А. Петрова, И. Антанасиевич, тщательное изучение периодики межвоенного времени Б. Чурича и другие исследования сделали достоянием науки богатейший материал.

Сегодня признано, что Югославия (прежде всего, Сербия) была важным центром русского рассеяния, прежде всего, духовным и религиозным. В 1921 г. недалеко от Белграда, в Сремских Карловцах, была основана Русская Заграничная православная церковь во главе с митрополитом Киевским и Галицким Антонием (Храповицким). На социальный состав диаспоры оказало влияние то, что в Белграде расположился штаб царской армии под командованием генерала Врангеля (Югославия приняла на своей территории части белой армии). Кроме того, в Югославию устремилась небогатая часть интеллигенции, чтобы найти здесь применение своим знаниям. Среди них были и крупные ученые, которые стали работать в Академии наук

3 См.: Шешкен А.Г. Белград - центр русской эмиграции на Балканах // Шешкен А.Г. Русская и сербская литературы: штудии по компаративистике. Белград. 2017. С. 245-263. 
и Белградском университете. Установлено, что большинство русских эмигрантов имели среднее и высшее образование, значительная часть из них были люди творческих профессий. Замечено, что русские влились в сербскую творческую среду, где на их долю приходилось порядка $10 \%$.

Писатели, определившие лицо русской литературы в первые десятилетия XX в., не выбрали Югославию для постоянного проживания, хотя многие из них здесь печатались и по разным поводам сюда приезжали (И. Бунин, С. Мережковский, И. Северянин, К. Бальмонт и др.). Главной особенностью поэзии «Русского Белграда» было то, что ее создавала молодежь, оказавшаяся вместе с родителями в Сербии и здесь повзрослевшая. Русские студенты получали стипендии от правительства страны, и в 1920-1930-е гг. составляли абсолютное большинство среди иностранных студентов Белградского университета. Первые поэтические кружки возникли именно в университетской среде.

Литературные кружки были центрами, объединяющими и организующими литературную жизнь молодежи в Белграде. На создание собственных печатных органов у нее не было средств. Это тоже важное отличие от крупных центров русского рассеяния, где издавались литературные журналы, но куда недегко было молодым авторам пробиться. Главным организационным центром творческой жизни русских стал «Союз русских писателей и журналистов в Югославии» (1925). ${ }^{4}$

4 «Союз» насчитывал около 200 членов, среди которых преобладали журналисты, публицисты и театральные деятели. Литераторов было немного. Учредителями выступили режиссер Ю. Ракитин, С. Страхов, А. Ксюнин. Председателем был избран П.Б. Струве. «Союз» принял под духовное покровительство король Югославии Александр I Карагеоргиевич. 
В начале 1920-х гг. произошло рождение «белградского поэтического круга» (при всей условности такого обозначения). Почвой для появления будущих талантов служили литературные кружки средних учебных заведений, русских кадетских корпусов и гимназий, открытых в Югославии. Например, один из ярких представителей молодого поколения эмигрантских поэтов И.Н. Голенищев-Кутузов (1904-1969) был организатором литературного кружка в первой русско-сербской гимназии (открыта в 1921 г.). В среде университетской молодежи сформировался литературный кружок «Гамаюн» (1923), который издал небольшой поэтический сборник «Гамаюн - птица вещая» (1924). Членами кружка и авторами сборника были: И. Голенищев-Кутузов, Ю. Бек-Софиев, А. Дураков, Г. Елалич, А. Фон Миран, Ю. Вереницын и др. Затем во второй половине 1920-х гг. возник «Книжный кружок», которым длительное время руководил его фактический организатор и вдохновитель Евгений Кискевич. В нем также участвовали Е. Таубер, Г. Наленч (наст. имя Г. Сахновский), И. Кондратович, Л. Кремлев, Вс. Григорович, Л. Машковский, А. Костюк, К. Кочаровский и др.

Кружки, как правило, существовали недолго и быстро распадались, молодежь взрослела и нередко покидала Белград. Екатерина Таубер, например, вышла замуж и уехала во Францию. Юрий Бек-Софиев (1899-1975) в начале 1930-х гг. уехал в Париж. Самым интересным по творческим результатам и долговечным был кружок «Литературная среда» (1934-1938), основанный И. Голенищевым-Кутузовым.

Молодая поэзии русских белградцев осознанно ориентировалась на поэзию Серебряного века, прежде всего, на лирику А. Блока. Об этом свидетельствует уже название литературного объединения «Гамаюн», 
отсылающее к стихотворению «Гамаюн, птица вещая», написанному Блоком в преддверии нового века (1899) и содержащему строки, полные страшных предзнаменований («казней ряд кровавых / И трус, и голод, и пожар, / Злодеев силу, гибель правых...»). Это стихотворение читалось в 1920-е гг. как откровение, как метафора потрясений, выпавших на долю русского народа. Выраженная в нем катастрофичность мироощущения, в принципе характерная для искусства русского символизма, была близка эмигрантской молодежи Белграда, как, впрочем, и пророчества Ф.М. Достоевского, предвидевшего кровавый хаос революции. Обращение к поэтическому опыту А. Блока превратилось в устойчивую тенденцию и прослеживалось в лирике белградских поэтов на протяжении 1920-1930-х гг.

А. Блок воспринимался в эмиграции не только как пророк судьбы России, но и как самый яркий певец исчезнувшего мира, представление о котором в значительной степени формировалось под воздействием его лирики. Этот особый, в значительной степени условный, мир можно назвать «Россией Блока», символом которой был Петербург, к тому времени исчезнувший с географической карты (его сменил Ленинград), но навсегда связанный своим именем с российской империей. А. Блок, вся жизнь которого была связана с этим городом, был, пожалуй, «самым петербургским» из всех предреволюционных литераторов, и по факту биографии (родился и умер в Петербурге) и по образности. Его поэзия представляет собой блестящий финальный аккорд классического «петербургского текста». Не случайно в поэзии русских эмигрантов и многочисленных воспоминаниях именно А. Блоку отведены самые протикновенные строки.

Поэтический мир русских белградцев - мир русский, но это мир литературный, навеянный не столько 
воспоминаниями о родине (они часто были скудными и почти стершимися), сколько с ее собирательным образом, изображенным в произведениях русской классики. Это особенно заметно в поэтических опытах совсем юных авторов, часто использующих образы Медного всадника и Петра I для выражения чувства национальной гордости. Наряду с А. Пушкиным заметна ассоциативная связь с М. Лермонтовым. «Разливы рек, подобные морям», и «лесов безбрежных колыханье» из лермонтовского стихотворения «Родина» оказывают воздействие на изображение русского пейзажа. Таких пейзажей не было возможности увидеть в тех местах, где юные авторы росли. Они видели «Боснийские горы», «мутноводную Саву» и «Дунай голубой». Эти пейзажные мотивы для них были более реальными, чем картины их родины. Игорь Лапко (1913-1931), (талантливый, но рано ушедший из жизни) связывает характерный для эмигрантской поэзии мотив тоски с опасением утратить четкость воспоминаний о России:

Тебя, тебя, моя страна,

Душа тоскующая ищет!

Но память о тебе скудна,

как самый обедневший нищий.

(Лапко И. Стихотворения. Белград, 1932. С. 25)

«Рок», «судьба», «тоска», «мираж», «видение», «грезы», «память» становятся постоянными атрибутами образа России в эмигрантской лирике не только старшего поколения, но и молодых стихотворцев. Белградские поэты свою связь с национальной культурой и атмосферой исчезнувшей России чаще всего выражали при помощи ассоциаций с образами дореволюционной блоковской лирики. Так, присутствие «блоковских мотивов» достаточно заметно в ряде стихов, опублико- 
ванных в сборнике «Белый стан» ${ }^{5}$ (без года, Белград). В стихотворении «Портрет» В. Григорович пытается воссоздать в памяти образ возлюбленной и рисует портрет «незнакомки», изменив, правда, цветовую гамму:

И чудится: означено слегка

В туманах платье белое трепещет

И нежный лик под темною косой

Сквозит из мглы всей чистотой овала

И оголенной тонкою рукой

К устам придвинуто стекло бокала.

В этом стихотворении на диалог с Блоком (стихотворение «В ресторане») указывают и «туманы», и «мгла», и «тонкая рука», и «бокал», в котором может быть только дорогое шампанское («аи», как у Блока), и игра света и тени. Образ женщины тоже почти нереальный, но нежный и бесконечно дорогой автору.

Явно подражает Блоку и другой автор сборника Анатолий Баташев: «Пара женских перчаток, надушенных тонко, // Недопитый бокал золотого Аи, // На кушетке уснувшая «Леди» болонка, // Вот и все, что осталось, когда Вы ушли».

Евгений Вадимов (псевд. Ю. Лисовского) в стихотворении-воспоминании «На острова», обращаясь к прошлому, прибегает к достаточно прозрачному ассоциативному ряду:

Наши встречи, взоры и слова

Станут сказкою - как станут так же сказкой

Летний Сад, Нева и Острова.

(Вадимов Е. Где-то: Сб. Белград, 1930)

5 В сборнике «Белый стан» опубликованы стихи Альбина Коморовского, В. Григоровича, П. Евграфова, А. Баташова, Николая Чухнова, А. Ваева. 
Тут ассоциативный ряд расширен за счет образа Летнего Сада, который в русском культурном сознании связан с пушкинским творчеством, его лирикой и романом «Евгений Онегин». Как и белые ночи, воспетые во вступлении к поэме «Медный Всадник». «Острова» же как петербургский топос адресуют к Блоку, воссоздавшему в своей лирике атмосферу любимого места гуляний и развлечений петербуржцев в конце XIX - начале XX вв. Три острова на северо-западе Петербурга (Каменный, Крестовский, Елагин) называли «царственным украшением русской столицы». Там располагались великолепные дворцы (творения знаменитых архитекторов Дж.Кваренги, А.Воронихина, К. Росси), роскошные дачи, сады, оранжереи, открывался красивый вид на Финский залив, особенно на закате. А. Блок эти места очень любил, что оставило след в его известных стихах. «Незнакомка» и гордая красавица из стихотворения «В ресторане», скорее всего, могли явиться поэту именно в этих местах, как и нежная девушка в белом платье («Мы встречались с тобой на закате...»).

Видения этих мест часто посещали поэтов русской эмиграции, успевших лично погулять и полюбить эту часть Петербурга: «Под пеплом печали храню я ревниво/ Последний счастливый мой день: / Крестовку, широкое лоно разлива/ И Стрелки заленую сень» (Саша Черный «Весна на Крестовском»).

Трагический диссонанс внутреннего мира и страстную жажду гармонии лирического героя раннего творчества А. Блока остро почувствовала и выразила Е. Таубер. Она посвятила А. Блоку целое стихотворение, в котором появляется один из наиболее примечательных и загадочных символов русской поэзии Серебряного века - образ Прекрасной Дамы. 
Ее он встретил в осенний вечер, Когда, как солнце, нам мир далек.

Он был измучен и странно светел Последний рыцарь - Блок.

Он грезил о стройной Даме,

О той, прекрасной, чей звездный след

Ему открылся в высоком храме

И был всю жизнь как бред.

(«А. Блоку»; Зодчий: Сб. Белград, 1927)

Молодые поэты поддерживали культурную миссию эмиграции - сохранение духовного богатства России и прямо заявляли о «необходимости продолжения русской культурной традиции». ${ }^{6}$ Важнейшим элементом этой традиции был язык. Красота родной речи, музыка ее звучания - эти атрибуты являются важной составляющей мотива памяти. Например, в лирике И.Н. Голенищева-Кутузова (сборник «Память», 1935) языюк относится к часто употребляемым словам, наряду со словами память, день, ночь, страсть, солнце, сон, звезды и многими другими, значимыми для его мифопоэтического мира («певучий сон о языке родном и богоданном» и др.)

Опора на предшествующую традицию русской литературы имела для становления поэзии «русского Белграда» важное значение, хотя поэты не забывают заявить и о попытках сказать свое слово в искусстве. В стихотворении «Стансы», посвященном Е. Таубер, И. Голенищев-Кутузов пишет:

Нет, не повторный лад и не заемный клад

В печальных звуках юношеских песен,

Мы знаем - каждый век по-своему богат

И каждый миг по-своему чудесен.

6 Зодчий. Стихи. Белград, 1927. С. 3. 
Глубоко трагический взгляд на мир, на судьбу человека в нем отразился в стихотворениях авторов «русского Белграда». Наиболее полно - в лирике И. Голенищева-Кутузова лирике, собранной в сборнике «Память» (1935). Мечты, видения, грезы, тоска о покинутой родине обусловили преимущественное обращение к жанру элегии поэтов. Их представление о родине были неконкретными и нечеткими, что и отразили их стихотворения.

\section{Ала Шешкен}

\section{СНОВИ О ИЗГУБљЕНОЈ ДОМОВИНИ И САНКТ ПЕТЕРБУРГУ У ПОЕЗИЈИ „РУСКОГ БЕОГРАДА“}

\section{Сажетак}

Тема сећања заузима централно место у поезији руске емиграције првог таласа, и међу песницима „руског Београда“ (И. Голенишчев-Кутузов, Е. Таубер, Ју. Лисовски, итд.). Тесно је испреплетена са темом отаџбине и чежње за њом, коју карактеришу замућени обриси, замагљене линије и књижевни квалитет. Најважнији оријентир за младе песнике били су текстови А. Блока и слика Санкт Петербурга створена у његовој дореволуционарној поезији.

Кључне речи: поезија руске емиграције првог таласа, „руски Београд“, тема матице, мотив сећања, слика Санкт Петербурга, А. Блок, И. Голенишчев-Кутузов. 